\title{
"I tried it and it is really good": Replicating Recipes of Arabic Black Inks
}

\author{
Claudia Colini
}

\begin{abstract}
The aim of this contribution is to present some case studies that highlight the key role played by the replication of recipes in both the Humanities and the Natural Sciences. In particular, I will present instances of how this approach can assist textual criticism, for example in the understanding of variants and errors, and in clarifying the meaning of some terms. By evaluating the feasibility of the recipes, their outcome and their order in the treatises, it is also possible to determine the technical skills of authors and compilers. Finally, the inks produced can be used as a reference for scientific analysis: not only by comparing these data with those obtained from the investigation of manuscripts, but also to assess the limits of the equipment, techniques and protocols used to undertake this investigation.
\end{abstract}

\section{Keywords}

Arabic manuscripts - ink recipes - scientific analysis

\section{Introduction}

The study of manuscripts' constituent materials has developed considerably in recent years. But alongside the use of increasingly refined non-destructive techniques and portable equipment, the need for an historiographical study of the materials known and employed for writing in the Arabo-Islamic milieu has become evident. In this view, historical sources, such as treatises on painting or calligraphy, can add information critical to the understanding of past epochs' technical knowledge and to the correct identification of the materials employed. But the study of these treatises must not be limited to their textual analyses and should instead be accompanied by the experimental reproduction of the recipes in order to yield the best results. Indeed, the replication of 
recipes can enhance understanding of the texts, which are sometimes unclear, and in evaluating the writers' competence in light of the corrections they made to the text they copied and of the different kinds of mistakes they might have introduced. Moreover, the inks produced can be used as a reference for scientific analyses: by knowing as precisely as possible which ingredients were used in a given recipe, it is possible to evaluate the effectiveness of protocols, techniques and instruments when attempting the identification of that ink's components. Furthermore, the recipes and the resulting inks can help explain abnormal or uncommon results observed through the application of scientific analysis on manuscripts.

With this interdisciplinary approach in mind, recent research has been conducted by collecting black ink recipes from written Arabic sources on bookmaking, then by assessing their feasibility, and finally by replicating some of them. These samples were artificially aged and analysed using an array of analytical techniques, mostly non-invasive and non-destructive, in order to build a database of Arabic inks and their ingredients and also to verify the limits of the portable equipment and of the techniques employed. ${ }^{1}$

The aim of this paper is to present some case studies that highlight the key role played by the replication of recipes in relation to a multitude of purposes: to spot possible mistakes in the tradition and to understand their transmission (case study I and II); to assess the author's technical skills (case study II, III and IV); to clarify the terminology (case study III and IV); to validate hypotheses based on analytical data (case study v); and finally, to assess the limits of the current analytical protocols and equipment (case study vi).

The main treatises taken into account in this chapter are: ${ }^{2}$

1 Claudia Colini, From Recipes to Material Analysis: The Arabic tradition of Black Inks and Paper Coatings (9th-2oth century), (PhD Diss., Hamburg University, 2018). The research presented in this article was carried out at the SF B 950 'Manuskriptkulturen in Asien, Afrika und Europa,' funded by the German Research Foundation (Deutsche Forschungsgemeinschaft, DFG) and within the scope of the Centre for the Study of Manuscript Cultures (CSMC). I would like to acknowledge the help received by Sara Fani, Cornelius Berthold, Beate Wießmüller and Tilman Seidensticker for the translation of the Arabic texts. My thanks go to Ira Rabin, Tea Ghigo and Sebastian Bosch for the fruitful discussions and other members of our department at the вАм and CSMC for sharing their analytical results with me: Oliver Hahn, Olivier Bonnerot, Zina Cohen and Ivan Shevchuck. I would also like to thank Ahmed Parkar for his assistance in the replication of the recipes from Kenya.

2 The literary sources for this study are selected from the Italian translation by Sara Fani and in the German translation provided by Armin Schopen, as well as in their Arabic original. See Sara Fani, Le arti del libro secondo le fonti arabe originali. I ricettari arabi per la fabbricazione degli inchiostri (sec. IX-XIII): loro importanza per una corretta valutazione 
- Zinat al-kataba ('The ornament of the scribes') by Abū Bakr Muhammad b. Zakariyyā̄ al-Rāzī, (d. 313 or 323/925 or 935);

- Umdat al-kuttāb wa-uddat dawi al-albāb ('The staff of the scribes and implements of the wise men') by al-Mu'izz b. Bādīs at-Tamīmī al-Ṣanhāğì (d. 454/1062); ${ }^{4}$

- al-Muhtara'fífunūn min al-șuna'('The findings on the techniques of craftsmanship') by al-Malik al-Muẓaffar Šams al-Dīn Yūsuf b. 'Umar al-Ġassānī (d. 694/1294-95);

- Kitāb al-azhār fí 'amal al-ạ̣bār ('The most beautiful flowers on the production of inks') by Muhammad b. Maymūn b. 'Imrān al-Marrākušì al-Ḥimyarī (7th/13th c.);

e conservazione del patrimonio manoscritto, (PhD Diss., Università "L'Orientale," Napoli 2013); Armin Schopen, Tinten und Tuschen des arabisch-islamischen Mittelalters, (Göttingen: Vandenhoeck \& Ruprecht, 2014); other recipes have been collected in the following precious contributions: Martin Levey, Mediaeval Arabic Bookmaking and Its Relation to Early Chemistry and Pharmacology (Philadelphia, PA: American Philosophical Society, 1962); Lucia Raggetti "Cum grano salis: Some Arabic Inks Recipes in their Historical and Literary Context," Journal of Islamic Manuscripts, 2016, 7/3:294-338; David James, "The Commentaries of Ibn al-Bașị̣ and Ibn al-Wahīd on Ibn al-Bawwāb Ode on the Art of Calligraphy (rā’iyyah fí al-hațț)," in Back to the Sources. Biblical and Near Eastern Studies in Honour of Dermot Ryan, edited by Kevin J. Cathcart \& Jeremiah F. Healey, (Dublin: Glendale 1989), pp. 164-191; Hossam Mujtar al-'Abbādī, Las artes del libro en al-Andalus y el Magreb (siglos IVh/XdC-VIIIh/XVdC), (Madrid: Ediciones El Viso, 2005); Michaelle Biddle, "Inks in the Islamic Manuscripts of Northern Nigeria: Old Recipes, Modern Analysis and Medicine," Journal of Islamic Manuscript, 2011, 2/1:1-35.

3 Lenn E. Goodman, "al-Rāzī," in Encyclopaedia of Islam, New Edition, edited by: P. Bearman, Th. Bianquis, C.E. Bosworth, E. van Donzel, W.P. Heinrichs, vol. viII pp. 474a-477b; Carl Brockelmann, Geschichte der Arabischen Litteratur, Band I (Weimar: Emil Felber, 1898), pp. 233-235; Carl Brockelmann, Geschichte der Arabischen Litteratur. Supplementband, Band I, (Leiden: Brill, 1937), pp. 417-421; Mahmoud Zaki, "Early Arabic Bookmaking Techniques as Described by al-Rāzì in His Recently Discovered Zīnat al-Katabah," Journal of Islamic Manuscripts, 2011, 2:223-234.

4 Mohamed Talbi, "al-Mu'izz b. Bādīs," in: Encyclopaedia of Islam, New Edition (cit. note 3), vol. vII pp. 481b-484a; Brockelmann, Geschichte I (cit. note 2), p. 268; Brockelmann, Geschichte Supplementband I (cit. note 3), p. 473; al-Mu'izz ibn Bādīs al-Tamīmī al-Ṣanhāğī, 'Umdat al-kuttāb wa-'uddat dawì al-albāb. Fïhi șifat al-hațt wa-l-aqlām wa-l-midād wa-l-liyaq wa-l-ḥibr wa-l-asbāà wa-ālat al-tağlīd, eds Naḡîb Māìl al-Harawī and 'Ișām Makkiyya. Mašhad: Mağma' al-Buhūt al-Islāmiyya, 1409/1988 H.Sh.

5 G.R. Smith, "Rasūlids," in: Encyclopaedia of Islam, New Edition (cit. note 3), vol. viII pp. $455^{\mathrm{a}-}-457 \mathrm{~b}$.

6 Muhammad b. Maymūn b. 'Imrān al-Marrākušī (al-Ḥimyarī), "Kitāb al-Azhār fì 'amal al-aḥbār li-Muhammad b. Maymūn b. 'Imrān al-Marrākuš̄i (al-qarn al-sābic al-hiğrī)," edited by Ibrāhīm Šabbūḥ, in Mağallat ta'rīh al-'ulūm al-'arabiyya wa-l-islämiyya = Zeitschrif für 
- Tuhafal-hawāṣş fituraf al-hawāșș ("The gifts of the wise men on the curiosities of the substances') by Abū Bakr Muḥammad b. Muhammad al-Qalalūsī al-Andalusī (d. 707/1308). ${ }^{7}$

\section{Case Study I — A Recipe of a Plant Ink or of an Iron Gall Ink with a Missing Line?}

In the first case study, I analyse one of the few recipes of plant inks recorded in the treatises. It has been found only in the treatise Tanwìr al-gayāhib fi ạkām dawät al-dawā'ib ('The illumination of darkness concerning the rules of those [preparations] containing soluble substances'), attributed to al-Qalalūsī. ${ }^{8}$ In my opinion, however, it is more likely that it is a combination of recipes from different sources, with the majority of recipes originating from Tuhaf al-hawāsș by al-Qalalūsī. In fact, while al-Qalalūsī called even the iron gall inks midād (a word used to identify mainly carbon inks), the term hibr is also used in Tanwir

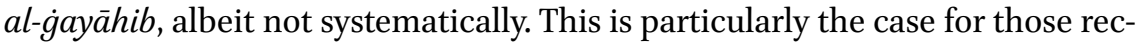
ipes not coming from Tuhaf al-ḩawāṣs.

\section{The Ink (hibr) of Abū Ṭāhir ${ }^{9}$}

It takes two and a half dirham of good gall nuts and the same amount of good gum. They are pulverized in a mortar. Twenty-five dirham of water are poured on it and it is rubbed until it is good and pure, God willing. ${ }^{10}$

geschichte der Arabisch-Islamischen Wissenschafen, 1422/2001, 14:41-133 (Arabic pagination), pp. 41-54.

7 Carl Brockelmann, Geschichte der Arabischen Litteratur, Band II (Weimar: Emil Felber, 1902), p. 336 (although his name is given as al-Qallūsī); Abū Bakr Muhammad ibn Muḥammad al-Qalalūsī al-Andalusī, Tuḥaf Al-Jawāṣṣ Fī Turaf Al-Jawāṣṣ (Las galanduras de la nobleza en lo tocante a los conocimientos más delicados), ed. Hossam Ahmed Mokhtar El-Abbady. Alexandria: Maktabat al-Iskandariyya, 2007.

8 Schopen, Tinten und Tuschen (cit. note 2), p. 27; MS Cairo Dār al-Kutub Utūm macā̌sìyya 46.

9 Schopen identified the person as Abū al-Faḍl Ahmad b. Abū Ṭāhir Ṭayfūr (204/819280/893), writer, scholar and historian; Schopen, Tinten und Tuschen (cit. note 2), p. 125, Brockelmann, Geschichte I (cit. note 2), p. 144; Brockelmann, Geschichte Supplement Band I (cit. note 3), p. 210; Fuat Sezgin, Geschichte des arabischen Schrifttums, Band I, (Leiden: E.J. Brill, 1996) p. 348.

10 See Schopen, Tinten und Tuschen (cit. note 2), p. 125; for the Arabic text, see Ms Cairo Dār al-Kutub 'Ulūm ma'āšìyya 46, f. 3ir. 
When I replicated this recipe, the colour of the ink was pale yellow and the writing on the paper almost invisible. According to Schopen, a similar recipe (that he does not translate) was used to write on parchment under the Zirid rule in Qayrawān (Tunisia). ${ }^{11}$ He himself tested Abū Tāhir's recipe on parchment obtaining a more visible ink, although it is still of a light yellow-brown colour.

Let us consider the steps of the recipe: 1) gall nuts and gum are pulverised in a mortar; 2) water is added; and 3) after rubbing and pounding the liquid for an unspecified length of time, the ink is ready. The solubilisation of tannins into water, however, is not immediate, something that the authors of ink recipes knew very well. In fact, in the recipes for iron gall inks, the tannins are often extracted by maceration, fermentation or cooking. In a few cases, the plants are used in the form of powders: these are the so-called instant ink (hibr min sā'atihī) or shadow ink (hibr zillīi).

As an example, I present here two recipes of this kind, both found in the same Tanwìr al-gayāhib treatise as the aforementioned one by Abū Țāhir, respectively two folios before and two folios after it:

\section{Good Ink (midād) for Paper}

Two dirhams of Byzantine gall nuts, the same quantity of gum arabic and one and a half dirham [of vitriol] must be taken and ground separately, then, twenty dirhams of water must be added to the gum after having ground it in a mortar, and it must be left until it melts. Then the ground gall nuts must be added to it, and then the vitriol, God willing. For parchment: the preparation is the same, with the addition of four dirhams of water and the subtraction of one dirham of gum. ${ }^{12}$

\section{Recipe for an Ink (hibr) that the Jurist al-Așilli Used to Employ}

Two dirhams of Byzantine gall nuts must be taken and ground finely; two dirhams of gum arabic must be taken and ground finely; each of them has to be placed separately. Then one dirham and a half of vitriol must be

\footnotetext{
11 Schopen, Tinten und Tuschen (cit. note 2), p. 125.

12 Translation by Lucia Raggetti; for the Arabic text, see ms Cairo Dār al-Kutub 'Ulūm ma'āšiyya 46 , f. $29 v$. Schopen refers to this recipe erroneously by placing it at f. $30 \mathrm{ov}$ and by considering it as the same preparation of the recipe of the ink used by al-Așilī. Moreover, the title he gave - Recipe for an ink (midād) for paper and parchment — does not appear in the manuscript but it is more likely his own synthesis. Schopen, Tinten und Tuschen (cit. note 2), p. 104.
} 
taken, ground and placed separately. Then consider: if the ink is meant for paper, take the gum, put it in a mortar, pour twenty dirhams of water on it, grind the gum with water until it melts. Then add the ground gall nuts and the vitriol and grind everything with water until they are well mixed. Then put this in a vessel and write with it, if you want, immediately.

If you want the ink to be for parchment, then the gum has to be one dirham and a half and the water two ounces, but you should not write with it until it has settled on the bottom. ${ }^{13}$

These two recipes for instant ink are very similar, especially in the part describing the ink for paper, as if the first preparation were a synthesis of the second. Interestingly, in the recipe of a good ink for paper the mention of vitriol is missing from the line where the ingredients are stated, possibly due to a mechanical error of omission, while its amount is given.

By comparing the part dealing with the ink for paper of these two recipes with that of Abū Tāhir, we can notice that they share the same procedures, the ingredient proportions (but not the actual figures) and even the textual structure, although the latter is more concise and some passages have been omitted. The obvious difference is that the vitriol is not mentioned among the ingredients and that the line stating the addition of vitriol to the solution is missing. It is my opinion, therefore, that the text of the recipe of Abū Țāhir is actually an incomplete recipe for an instant iron gall ink that, due to errors in the course of the textual transmission - again mechanical errors of omission, possibly due to the repetitive formulations typical of recipes - looks like a recipe for a plant ink. Two other elements support this hypothesis: among the few plant ink recipes that have been collected, all instruct the reader to extract the tannins by fermentation or cooking; none of the aforementioned recipes use gall nuts, mentioning instead other vegetal tannin sources, with a single exception that mixes damascene mulberries with a little extract of gall nuts. ${ }^{14}$

13 Translation by Lucia Raggetti; another translation is in Schopen, Tinten und Tuschen (cit. note 2), p. 103-104; for the Arabic text, see Ms Cairo Dār al-Kutub Ulūm ma'ā̌siyya 46, f. 33 r.

14 The recipe can be found in al-Marrākušì's Kitāb al-azhār and refers specifically to the "water of gall nuts"; Fani, Le arti del libro (cit. note 2), pp. 97-98; and al-Marrākuš̄i, Kitāb al-azhār (cit. note 6), p. 85 . 


\section{Case Study II - An Error and a Wrong Correction}

In this case study, I analyse a recipe for iron gall ink that is part of the treatise Tuhaf al-hawāṣs by al-Qalalūsī. The edition takes into account both the surviving manuscripts: MS Paris BnF Arabe $6844^{15}$ and Ms Rabat al-Hizāna al-Malikiyya $8998 .{ }^{16}$ In the recipe to prepare a midād by cooking, we find a significant technical variant:

\section{Another Midād Obtained by Cooking}

One ounce (üqiyya) and a quarter of gall nuts must be taken and ground finely in a mortar. One rațl of fresh water must be poured on them and they must be left to rest for one night and one day. One ounce of gum [MS Paris BnF 6844] / half ounce of vitriol [Ms Rabat al-Hizāna al-Malikiyya 8998] must be taken, ground in the mortar and the macerated gall nuts must be poured onto it, in a quantity that is enough to cover it, and it is left to rest for one day and one night until the water becomes red. At this point, the gall nuts are cooked on a low fire until a third has evaporated. They are sieved through a cloth in a clean vessel, then the gum is added while stirring; add to the mixture what you like until its tone satisfies you. ${ }^{17}$

The formula in the Paris manuscript is ineffective since the gum appears twice and the vitriol is missing. Most likely, one mention of the gum arabic was meant to be vitriol, but the scribe of this manuscript or of its model made a simple and trivial mistake while copying. The formula in the Rabat manuscript is, on the other hand, perfectly functional, with all the needed components mentioned, since the third sentence of the Rabat copy has "half ounce (üqiyya) of vitriol" instead of "one ounce (üqiyya) of gum" as found in the Paris manuscript. At first glance, a scholar might be tempted to correct the first formula with the second one, but by reading more carefully and reproducing them, it

15 The manuscript is composed of several units added to a core consisting of multiple texts copied by the same copyist, Muhammad ibn Ahmad al-Guraybī; the aforementioned treatise can be found in this core at ff. 112v-133v, it is dated at the end of dū al-hiğğa 986/ January 1578; Fani, Le arti del libro (cit. note 2), p. 134; Schopen, Tinten und Tuschen (cit. note 2), p. 27 .

16 The severely damaged manuscript is dated Friday, middle of the month of Ğumādà al-ülà 993/ middle of May 1585. The name of the copyist is not given in the colophon; Fani, Le arti del libro (cit. note 2), p. 134; Schopen, Tinten und Tuschen (cit. note 2), p. 27.

17 See Fani, Le arti del libro (cit. note 2), pp. 138-139; and al-Qalalūsī, Tuhạf (cit. note 7), pp. 22-23. 
is clear that the first occurrence of gum arabic should be indeed gum arabic, while it is the second one that should have been vitriol. In fact, if gum arabic is added to macerating gall nuts it does not stop the process of extraction and the water will turn red-brown for the solubilization of the tannins (Fig. 7.1 B and B2). By contrast, adding vitriol to the gall nuts will result in a black solution and not a red one, as stated in the recipe, even if it is left for one day and one night (Fig. 7.1 A and A2).

Moreover, the last sentence of the recipe instructs the reader to add "what you like" in order to adjust its tone. But the intensity of the colour is not regulated by gum arabic, which influences the viscosity and the shine, but rather by vitriol. It thus makes more sense that the last ingredient added is vitriol and, since no amount is specified, the last sentence should be interpreted as "add to the formulation as much [vitriol] as you like until its tone satisfies you."

It is possible, then, that the scribe who wrote the Rabat manuscript (or its precursor) noticed the repeated ingredient in the passage he was copying and tried to correct the mistake: unfortunately, he corrected the wrong entry. In addition, in the version represented by the Rabat manuscript, the amount was reduced from one ounce (üqiyya) to half of it, since the same quantity of vitriol and gall nuts for an ink prepared by maceration and decoction would have resulted in a formulation with an excess of iron and sulphuric acid that would probably have pierced the support. Both the corrections prove that the copyist, or the copyists, had a certain degree of competence but that they probably did not try out the recipe or else they would have noticed the inconsistency in the description. ${ }^{18}$

\section{$4 \quad$ Case Study III — Sumac Ink: Black or Red?}

In the third case study, I concentrate on three versions of a recipe for an ink made with vitriol, sumac and gum arabic that can be found in the Umdat $a l-k u t t a \bar{b} b$ by ibn Bādīs, in the Muhtara' fí funūn by al-Malik al-Muzaffar and in the Kitāb al-azhār by al-Marrākušì.

18 For the sake of clarity, I decided to simplify my reconstruction, although many possibilities could describe what really happened in the transmission of the recipe; unfortunately, the exact relation between the Paris and the Rabat manuscripts has not yet been investigated. Whatever the transmission might have been, it does not change the result: the corrections suggest a reasoned approach with some degree of competence in ink preparation. 

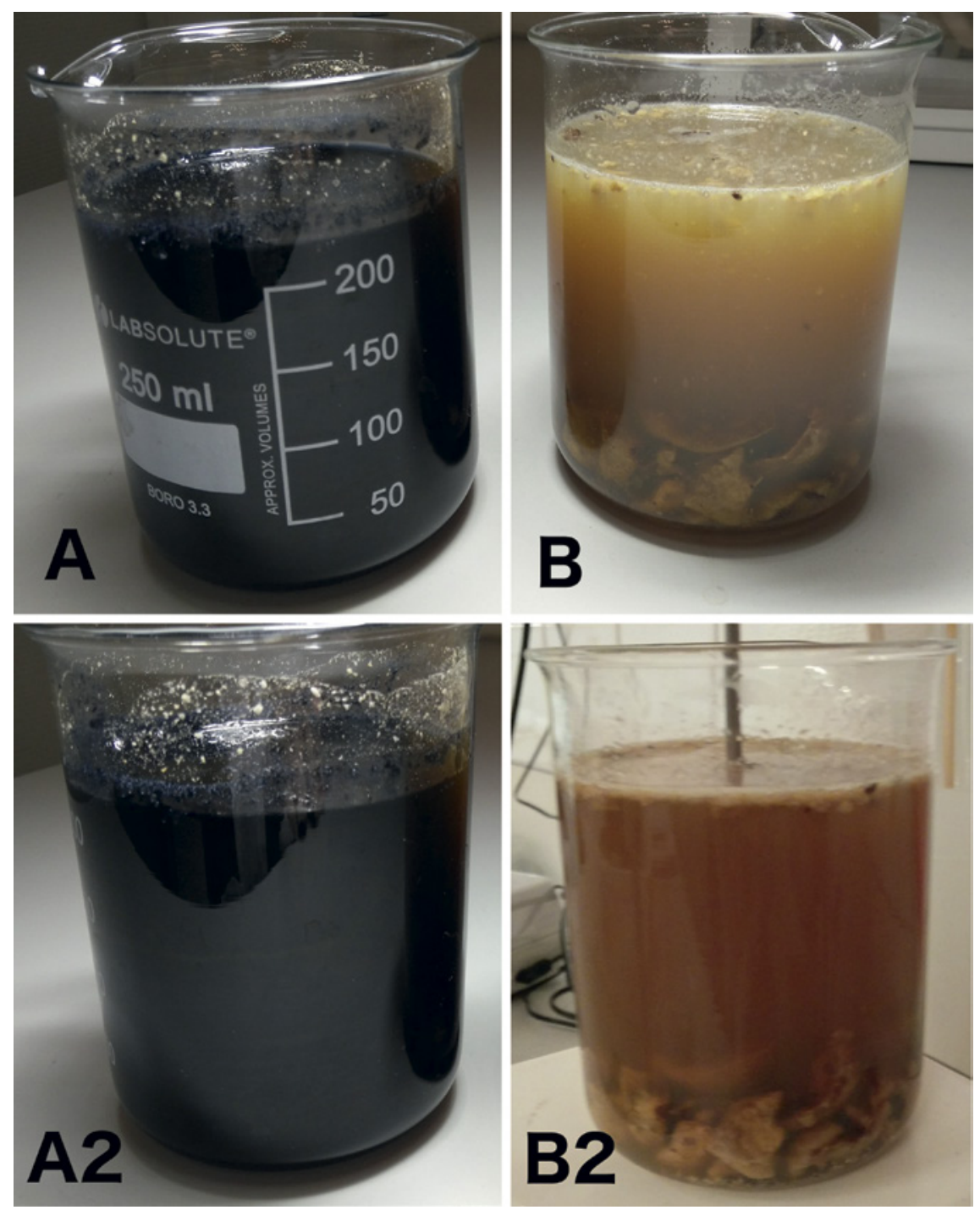

FIGURE 7.1 Reproduction of the recipe by al-Qalalūsī: A) addition of vitriol to the solution of gall nuts (MS Rabat al-Hizāna al-Malikiyya 8998); B) addition of gum arabic in the solution of gall nuts (my reconstruction); A2) solution A after 24 hours; B2) solution B after 24 hours 
The recipes in the Muhtara' $f \grave{l}$ funūn and in the Kitäb al-azhār are similar, although a different unit is used for the measuring of the gum arabic: three rațl of fresh water are poured over a quarter rațl of sumac from Sinǧăr and the solution is left for two days in the sun. The residue is pounded and the solution strained. Then, for every rațl of solution, five üqiyya (Muhtara' fífunün) or five istār (Kitāb al-azhār) of gum arabic are slowly added: one ounce (üqiyya) / istār is added every day and then the solution is left in the sun. Finally, the vitriol is incorporated. ${ }^{19}$

The recipe in 'Umdat al-kuttāb is different: one rațl of sumac is cooked in six rațl of water and, after the residue has been pounded and the solution filtered, five ounces of gum arabic are added to the solution. Once the gum dissolved, the vitriol is added. ${ }^{20}$

The word sumac (summāq) refers to a very useful plant: its fruits are used as spice and as a red dye, while its leaves and bark are traditionally employed in leather tanning. The recipes, however, do not specify which part of the plant should be used. All three recipes describe how the red colour will appear after the maceration or cooking of the sumac. This might be an indication of the use of fruits, however the red colour is also (though not always) mentioned when describing the liquid obtained from the maceration of gall nuts, thus it could refer to the colour of tannins, independently from the source. In both 'Umdat al-kuttāb and Muhtara'fifunün however, this ink description has been placed among those for coloured inks, while in Kitāb al-azhār it is recorded among those for black ones. The latter seems more logical to me, especially if leaves and bark were to be used, since they contain tannins that will react with the iron in the vitriol forming the black ferro-gallate complex.

I decided to test the recipe in 'Umdat al-kuttāb using the fruits of sumac in order to see whether I could obtain a red ink. I put $30 \mathrm{~g}$ of sumac spice in $180 \mathrm{~g}$ of water and heated it until it reached boiling point. The recipe says to cook it "until the red appears" but the water became red right from the start of the cooking process and after 15 minutes I did not see any noticeable change in the colour of the water, although the spice gradually became pink-brown (Fig. 7.2 A). After straining the solution through a gauze, I added $12 \mathrm{~g}$ of gum arabic and waited for it to dissolve completely (this took about a day). I then added the vitriol and the liquid blackened immediately. After $6 \mathrm{~g}$, the solution was very dark with some nuances of red-violet.

19 See in Fani, Le arti del libro (cit. note 2), pp. 63 and 9o; Schopen, Tinten und Tuschen (cit. note 2), pp. 116-117; al-Marrākušī, Kitāa al-azhār (cit. note 6), p. 76 .

20 See Schopen, Tinten und Tuschen (cit. note 2), p. 117; and Ibn Bādīs, 'Umdat al-kuttāb (cit. note 4$),$ p. 5 o. 

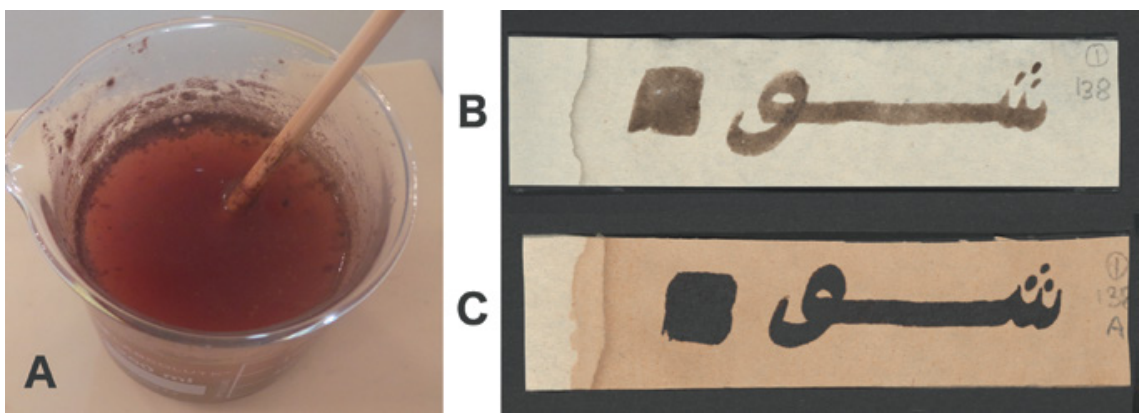

FIGURE 7.2 Sumac ink: A) extract from sumac fruit after boiling; B) sample of ink before ageing; C) sample of ink after ageing

This test proves that it is possible to obtain a black ink even from the fruit and therefore it is odd that both ibn Bādīs and al-Malik al-Muẓaffar inserted the recipe among coloured inks. It is possible that, knowing that a red dye can be obtained from the fruit of sumac, they overlooked the addition of vitriol and assumed it was a red ink. This demonstrates, however, that neither of them tested the recipe before assigning it to the right chapter, as they probably just took them over from their written sources. The position of this ink in the text speaks to the technical skills of the compilers, or rather their lack thereof.

Al-Marrākušì, on the other hand, was aware that after the addition of the vitriol the solution would become black; he specifically mentions this in his recipe. It is possible that he tried the ink before composing the text, thus demonstrating both his competence in the matter and a bibliographical attitude. It is still unclear, however, which part of the plant he is referring to. Considering that the colour of the solution made with the fruits was not stable and quickly faded into a red-brown, it is more likely that he intended the leaves and bark to be used (Fig. 7.2 B). In any case, even this ink turned extremely black after ageing (Fig. 7.2 C).

\section{$5 \quad$ Case Study IV - Identification of Vitriols}

In this case study, I initially focus on the recipe attributed to the physician Buhtǐš $\bar{u}^{\mathrm{c}, 21}$ and then discuss the terms used for vitriols and the identification of

21 Dominique Sourdel, "Bukhtīshū'," in: Encyclopaedia of Islam, New Edition (cit. note 3), vol. I p. 1298. Schopen identifies him with Gibrīl b. Buhtǐšūc (d. 212/827), however, almost all the members of this family were physicians and bore similar names, thus the identification cannot be certain. See Schopen, Tinten und Tuschen (cit. note 2), p. 89. 
the corresponding salts. The last sentence of the aforementioned recipe must have been particularly difficult to understand for later authors and compilers of other treatises, as it spawned three redactions with three different formulas.

\section{Preparation of the Ink of Buhtīšü, the Physician}

Take one mikyāl of ground gall nuts and eight mikyāl of water and cook them in a saucepan until one quarter of it has evaporated. Then, you remove it from the fire and leave it until it has cooled down. Strain it through a tight mesh rag and put it in a vessel. Add a sufficient amount of $z \bar{a} \check{g}$ (vitriol) and qalqand (green vitriol) and, in the same way, gum arabic, then write with it. ${ }^{22}$

Recipe for an Ink from the Buhtiššu the Physician, According to What Has Been Transmitted

Take one part of perfect gall nuts, pound them, pour on them eight parts of fresh water and cook them in a saucepan until a quarter of it has evaporated. Then, take it from the fire and leave it until it has cooled down. Then, strain it through a tight mesh rag and put it in a vessel. Then, add the required amount of qalqand (green vitriol), of good quality vitriol and the same amount of gum arabic. You write with it and it will be excellent, God willing. ${ }^{23}$

An Ink (midād) from Buhtīšūc, Mentioned by al-Rāzī [Ms Paris BnF Arabe 6844] / Another Ink (midād) Mentioned by al-Rāzī [MS Rabat al-Hizāna al-Malikiyya 8998]

Take one mikyāl of ground gall nuts and eight mikyāl of water. Cook them in a saucepan until a quarter of it has evaporated. Then, let it cool down and strain the formulation through a tight mesh rag. Add a sufficient amount of vitriol; once you have pounded it enough, do the same with the gum. ${ }^{24}$

See Fani, Le arti del libro (cit. note 2), p. 47; and Muhammad ibn Zakariyyā’ al-Rāzī, Zīnat al-kataba, ed. Luțf Allāh al-Q̄ārī, 'Ālam al-Mahtūțāt wa-l-Nawādir, 1432/2011:211-242, in particular pp. 225-226.

23 See Fani, Le arti del libro (cit. note 2), p. 93, Schopen, Tinten und Tuschen (cit. note 2), p. 89; and al-Marrākušī, Kitāb al-azhār (cit. note 6), p. 8o.

24 See Fani, Le arti del libro (cit. note 2), p. 137; and al-Qalalūsī, Tuhaf (cit. note 7), pp. 21-22. 
Al-Rāzī wrote that gum arabic and two different types of vitriol, a generic one $(z \bar{a} \bar{g})$ and so-called qalqand, should be added at the end of the preparation, although no proportion or precise amount are given. Al-Marrākušs’s version is slightly different, since in his recipe the gum arabic should be added in the same quantity as the vitriol. Then, as in the Zinat al kataba, the same two types of vitriol are mentioned but the unit (mikyāl) was substituted with parts, possibly because that measure was no longer in use in Baghdad in the 13th century. Al-Qalalūsī, on the other hand, did not change the unit and, as al-Rāzī, understood that the gum had to be added to the preparation using the same method, but not necessarily in the same quantity as the vitriol. However, only one type of mineral, $z \bar{a} \ddot{g}$, is mentioned. It is hard to guess the reason for which al-Qalalūsì did not mention qalqant, especially considering that he described it, in the last paragraph of the chapter on black inks, as one variety of vitriol. It remains possible, however, that the omission could be a change produced in the course of the transmission.

What is, then, the exact meaning of those terms? In the following paragraphs, I shall try to reconstruct a hypothesis of identification.

$Z \bar{a} g$ is the generic term for vitriol. It can be followed by adjectives specifying its colour or its place of origin. ${ }^{25}$ The most frequently mentioned colours are yellow, green and white but it is extremely difficult to understand the chemical composition of these salts: they may refer to iron (III) sulphate (yellow), iron (II) sulphate (green) and zinc sulphate (white). Copper sulphate is blue in colour but there is no mention of blue vitriol in the treatises (Fig. 7.3).

Al-Rāzì explains some terms in his Kitāb al-asrār ('Book of Secrets'):26 qalqant/qalqand corresponds to green vitriol (zāğ ahḍar), which, according to the procedure for its purification, seems to be copper (II) sulphate; ${ }^{27}$ qul-

25 The regional indications are often too generic to precisely identify an area, as with Persian or Byzantine vitriol, and even when they are more precise, such as vitriol from Cyprus or from Kerman, several mines and consequently several types of vitriol have been found that correspond to the same area. Schopen, Tinten und Tuschen (cit. note 2), pp. 198-206. Moreover, the possibility that the names might actually be commercial labels must be considered. For example, is Cypriot vitriol a vitriol extracted from mines in Cyprus, or just a product typology similar to contemporary "Marseille soap," which identifies a product with recognisable characteristics but no real connection to the eponymous location?

26 Julius Ruska, Al-Rāzı̀s buch Geheimnis der Geheimnisse (Berlin: Julius Springer, 1937).

27 The procedure to prepare it: "Dissolve vitriol in water. Purify it. Throw on it copper filings and heat it until it is green. Purify it. Put it in a copper vessel. Dissolve it after you have put a half dirham of salt-ammoniac into ten dirhams of it."; Levey, Medieval Arabic Bookmaking (cit. note 2), p. 16, n. 88, Fani, Le arti del libro (cit. note 2), p. 226. According to this preparation method, it seems that the goal is a purification of an impure vitriol (probably a mixture of copper and iron sulphates) in an excess of copper solution to obtain a 


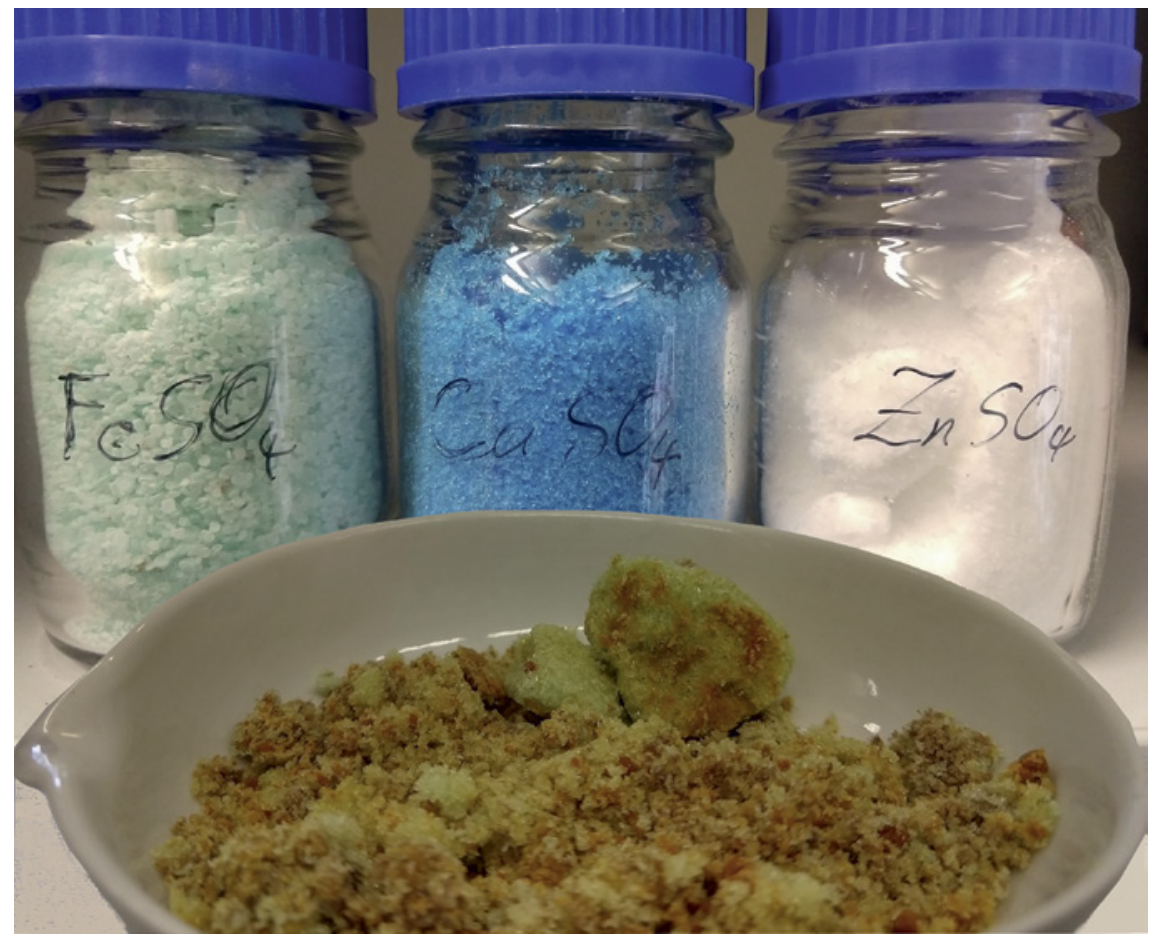

FIGURE 7.3 Colours of various vitriols; top from left to right: pure iron (II) sulphate (green), copper (II) sulphate (blue) and zinc sulphate (white); bottom: mixture of iron (II) sulphate (yellow), iron (III) sulphate (green) and iron oxides (red)

quțār/qalqațār corresponds to yellow vitriol (zāă asfar), although he does not explain how to obtain it; qalqandīs/qalqadīs refers to white vitriol (zāğ abyaḍ) also called šabb, alum, which is potassium aluminium sulphate. ${ }^{28}$

Al-Marrākušì does not clarify any of the terms in his works, while al-Qalalūsī describes some of them in the last paragraph of the chapter on black inks. The text is unfortunately only partially legible due to damage to the manuscripts. He says that qalqant is green vitriol, while qulquțār, also called shoemakers'

precipitate of metallic salts with a solubilization index lower of copper chloride, such as Fe (II) chloride. The solution will then contain copper ions, sulphuric acid and ammonium cations.

28 Procedure for its purification: "Take white pure alum. Dissolve and purify it. Distil vitriol and verdigris. Mix them with water of the purified alum and leave it in a beaker," Levey, Medieval Arabic Bookmaking (cit. note 2), pp. 16, n. 88, Fani, Le arti del libro (cit. note 2), p. 226. 


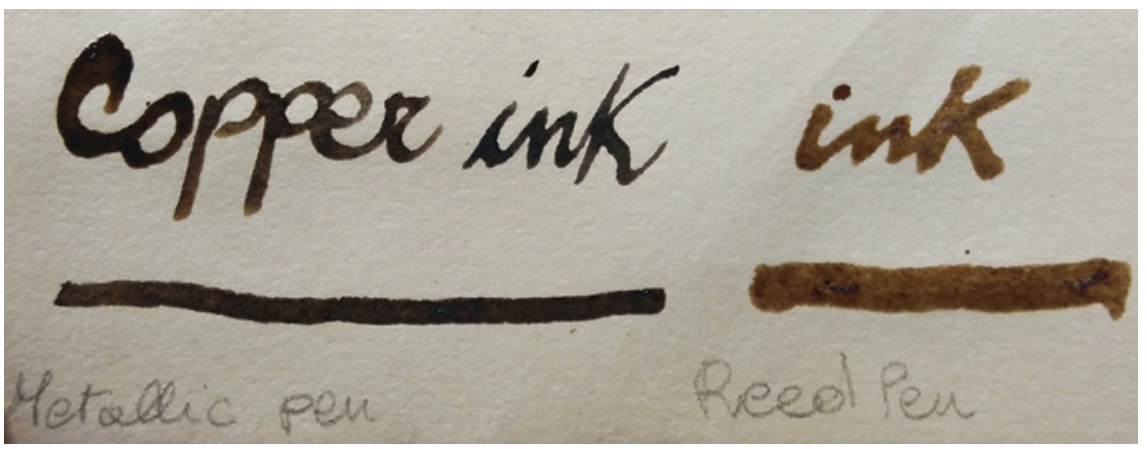

FIGURE 7.4 Sample written with copper ink: on the left, application with a metallic pen; on the right, application with a reed

vitriol, ${ }^{29}$ is the best, reacts quickly and does not leave mineral residues. He also informs us that Persian vitriol is clear and pure and, although a lacuna on the leaf prevents the reading of the colour, it does not have the hue of lapis lazuli (lāzuwardī). In another part of the text, ${ }^{30}$ the qulquțār is described as oxidized green vitriol, which, if we assume that green vitriol is iron (II) sulphate, should correspond to iron (III) sulphate, yellow in colour.

Green vitriol is the type most frequently mentioned in the recipes; thus, it is arguably the most effective. This would make sense if it referred to iron (II) sulphate, while al-Rāzì's identification with copper (II) sulphate is quite surprising.

In fact, copper (II) sulphate (blue in colour) does not form a black complex with gallic acid. To confirm the hypothesis, I conducted a simple experiment. I cooked $15 \mathrm{~g}$ of gall nuts in $30 \mathrm{~g}$ of water for ten minutes after boiling. I then progressively added pure copper (II) sulphate (o,3 g) to the still warm solution: it turned dark brown. I used it to write with a reed pen on handmade paper with no iron: as a result, the ink had a light brown colour (Fig. 7.4).

But what happens if some iron comes into contact with the solution? I used the same ink on the same paper but this time I wrote with a metallic pen, obtaining a very dark brown colour (Fig. 7.4, right side). This is due to the ionic exchange that happens when a solution with copper ions comes into contact with solid iron, caused by the different reactivity of the elements involved. In this case, the iron ions from the pen replace the copper ones in the ink

29 Pliny called copper sulphate (blue vitriol) "shoemaker black" (34.123); Pliny, Natural History, ed. and transl. by Harris Rackham, vol. 9: Books XxxıII-Xxxv (The Loeb Classical Library, 394) (Cambridge, MA: Harvard Univ. Press, 1995).

See Fani, Le arti del libro (cit. note 2), p. 145; and al-Qalalūsī, Tuhaf (cit. note 7), p. 28. 
solution; the copper ions then solidify on the tip of the pen. Subsequently, the iron ions form the complex with the gallic acid in the solution, as is usual for iron gall inks. Since this exchange involves a small number of ions, the resulting colour is only dark brown and not black. It is important to remember, however, that the vitriols mined and then sold on the markets were never pure. In particular, iron sulphate was often obtained as a by-product of the mining of copper, thus traces or even consistent amounts of copper in iron sulphate and vice versa are not surprising. It is possible, then, that green vitriol referred to a more generic mixture of iron and copper sulphates, even taking into account the respective colours of the salts. The same consideration, however, cannot be made for the term qalqand/qalqant, at least not for the identification made by al-Rāzī in his in Kitāb al-asrār. It is possible nonetheless that the meaning of the term shifted over time and from place to place, towards a more general identification with green vitriol.

The presence of other metals in the vitriols has been seen as an opportunity in archaeometry, since the type of the impurities and their relative quantity can be used for provenance studies and to differentiate formulations of iron gall inks and mixed inks. This is particularly effective for the application of the fingerprint model ${ }^{31}$ on the results obtained through X-Ray Fluorescence (XRF).

\section{Case Study v — Non-vitriolic Iron Gall Ink}

In the fifth case study, I analyse a type of iron gall ink made with iron filings or nails instead of the more common vitriol.

This ink was theorized as one of the first steps in the development of ferrogallic inks on the basis of evidence from manuscripts: in a recent study of Coptic manuscripts, several fragments dating from the 7 th to the 1oth century presented inks in which only iron and a small amount of manganese were identified using XRF, while copper and zinc, often associated with iron in vitriols,

31 The fingerprint model provides the ratio $\left(\mathrm{W}_{\mathrm{i}}\right)$ between minor constituents, such as manganese, copper and zinc, and the concentration of iron, having excluded the contribution of the writing support; Oliver Hahn, "Analyses of Iron Gall and Carbon Inks by Means of X-ray Fluorescence Analysis: A Non-Destructive Approach in the Field of Archaeometry and Conservation Science," Restaurator, 2010, 31:41-64, pp. 47-48; Wolfgang Malzer, Oliver Hahn, Birgit Kanngießer, "A Fingerprint Model for Inhomogeneous Ink Paper Layer Systems Measured with Micro X-ray Fluorescence Analysis," X-Ray Spectrometry, 2004, 33:229-233. 
were completely absent. ${ }^{32}$ This can be due to an extremely pure vitriol but it is more likely that a different source of iron was employed. There are, however, no recipes from this time confirming the hypothesis.

Among the Arabic recipes, a small number mentions the use of iron filings or nails either on their own, or as an addition to vitriol. The former use is described by several authors: a recipe can be found in the Kitāb al-azhār by al-Marrākušì; ${ }^{33}$ another one is in Tuhaf al-hawāsș by al-Qalalūsīin and also reformulated by an anonymous Sicilian scribe; ${ }^{35}$ another is in Ahmad ibn 'Iwaḍ ibn Muhammad al-Mag̈ribī's in Kitāb qatf al-azhār fì hawāṣs al-ma'ādin wa-l-ahğăr ('Book of the chosen flowers about the properties of metals and stones'); ${ }^{36}$ others are still used nowadays in sub-Saharan Africa, in particular in Kenya, Mali and Nigeria. ${ }^{37}$ The distribution of the recipes shows that such ink typology was known and has remained in use until the present days, at least from the middle of the 13th century, the date of the oldest surviving attestation. In fact, the results of the analysis of the Coptic fragments suggest that the origin of this ink typology is older. It is also possible that the survival of this ink typology is due to the accessibility of the necessary ingredients, especially when vitriol, which was generally preferred for its ease of use, was not available on the market.

Although the polygenesis of this typology is very likely, the recipes are similar: the source of tannins, i.e. being gall nuts, bark from wild olive trees or mangroves, seed pods of the Egyptian thorn, or witchweed, is soaked in water, left to macerate or, more often, boiled with the iron pieces (in the form of filings, slags or rusty nails). In some recipes, an acid source, such as lemon juice, vinegar or date vinegar, is mentioned: it can be used to soak the iron before

32 The project and some of the results have been published in Tea Ghigo, Olivier Bonnerot, Oliver Hahn, Ira Rabin, Myriam Krutzsch, "An Attempt at a Systematic Study of Inks from Coptic manuscripts," Manuscript Cultures, 2018, 11:159-166, pp. 162-163.

33 See Fani, Le arti del libro (cit. note 2), p. 111, Schopen, Tinten und Tuschen (cit. note 2), p. 98 and al-Marrākušì, Kitāb al-azhār (cit. note 6), p. 102.

34 See Schopen, Tinten und Tuschen (cit. note 2), p. 124.

35 Eugenio Griffini, "Nuovi testi arabo-siculi" in Centenario della nascita di Michele Amari, (Palermo: Virzì, 1910), Vol. 1 pp. 443-448.

36 Manfred Ullmann, Die Natur- und Geheimwissenschaften im Islam (Leiden: Brill 1972), p. 137; for this recipe see also Schopen, Tinten und Tuschen (cit. note 2), p. 99.

37 Ahmed Parkar collected a recipe from Kenya made with mangrove wood, lemon juice and rusty nails, which was reproduced during the course of this study, see Colini, From Recipes to Material Analysis (cit. note 1) pp. 94-95, Eva Brozowsky replicated inks from Mali, including some using local plants and nails, while examples from Nigeria using nails and local plants and date vinegar can be found in Biddle, see Biddle, Inks of Northern Nigeria (cit. note 2), pp. 14-16. 
mixing with the tannins or added after the boiling of the plants and the filings. The first procedure results in the production of iron ions and their reduction from iron (III) ions to iron (II) ions $\left(\mathrm{Fe}^{3+}\right.$ to $\mathrm{Fe}^{2+}$ ), which react with gallic acid forming the iron (II) gallate complex. It is interesting to note that, although the black pigment is due to the iron (III) gallate complex, the latter is poorly water soluble, while the transparent iron (II) gallate complex is highly soluble, meaning that the black complex tends to precipitate if a huge amount of it is formed in the inkwell. It is therefore easier and more effective to write with an ink consisting of little precipitate, i.e. with part of the molecules in an iron (II) gallate state, which turns completely black only after being applied to the writing support; that is, when the iron (II) gallate complex is oxidized by the oxygen in the air into iron (III) gallate. For this reason, the efforts of the ink makers focused on procedures that led to obtaining iron (II) ions, or else the reaction would be in favour of iron (III) gallate complex, with the ink then resulting in a dispersion rather than a solution. ${ }^{38}$ The addition of the acid after boiling the tannins may serve a similar purpose, since an acidic environment prevents the oxidation reactions turning iron (II) ions into iron (III) ions $\left(\mathrm{Fe}^{2+}\right.$ into $\mathrm{Fe}^{3+}$ ). But tannic extracts have a $\mathrm{pH}$ ranging from two to three, comparable to that of vinegar and lemon juice, therefore the change in acidity of the solution obtained by the addition of the acid should not be relevant. However, acid other than tannins act to produce iron (II) ions $\left(\mathrm{Fe}^{2+}\right)$ without binding iron, resulting in a better stoichiometric relation between iron and tannins. In fact, the two reproduced recipes made with the addition of acid (from contemporary Kenya and al-Qalalūsìs treatise, Fig. 7.5 A and 7.5 B respectively) have a darker colour after ageing than the one made without (by al-Marrākušì, Fig. 7.5 C).

Interestingly, al-Marrākušì was aware of the resulting colour, as the title of the preparation, "Production of an ink that comes out in the mahri colour"39 shows; moreover, it is included in the chapter on coloured inks, not in the chapter on black hibr (iron gall inks). This is further proof of his competence and possibly of the effort he put into testing his recipes before recording them.

The results obtained by XRF analysis of the samples made with the reproduced inks are comparable to those observed on manuscripts, thus

38 It is possible that the vitriol was preferred over the iron filings to make iron gall inks because of the difficulty and length in producing a good ink with iron oxides, although the preparation is more stable in time since no sulphuric acid is present. und Tuschen (cit. note 2), p. 98; Fani, however, translates it as the colour of the fruit of the colocynth, Fani, Le arti del libro (cit. note 2), p. 111; for the Arabic, see al-Marrākušì, Kitāb al-azhār (cit. note 6), p. 102. 


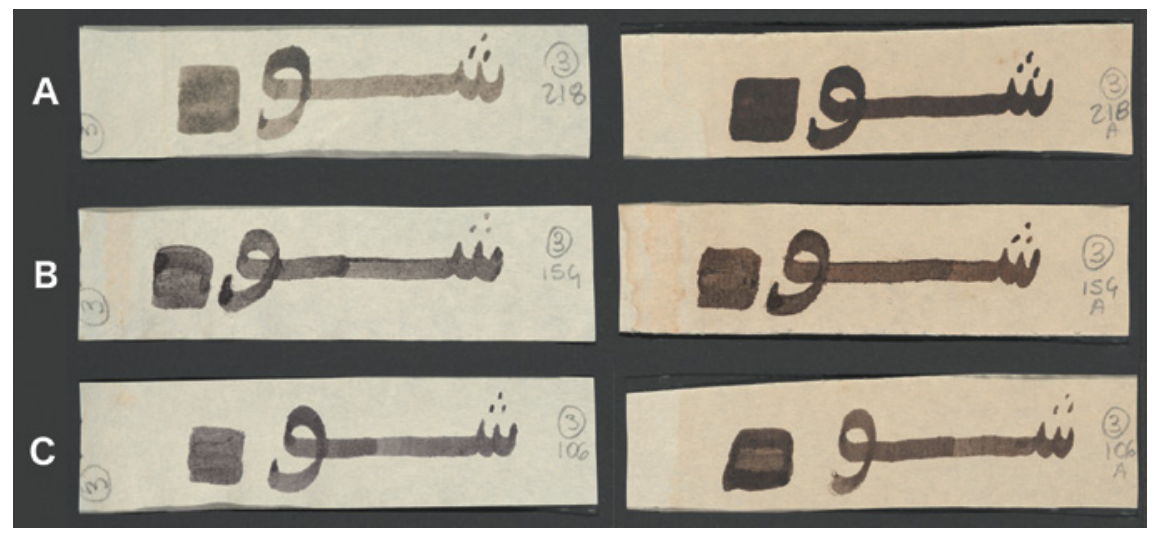

FIGURE 7.5 Samples written with iron gall inks made with iron filings before (on the left) and after (on the right) ageing: A) recipe from contemporary Kenya, ink made with mangrove bark, lemon juice and rusty iron filings; B) recipe by al-Qalalūsī, ink made with bark, vinegar and iron filings; $\mathrm{C}$ ) recipe by al-Marrākušī, ink made with gall nuts, iron filings and gum arabic

confirming that the analysed Coptic inks may have been produced with iron filings, slags or nails.

For the last case study, I am considering an entire typology of inks: the mixed inks. They have been described by Zerdoun as such: "Ce sont par exemple des encres au carbone auxquelles le préparateur a ajouté des extraits aqueux de produits tannants ou des sels métalliques; ce sont également des encres métallo-galliques dans lesquelles on a incorporé du noir de fumée." 40 Gacek says of them, "mixed inks consist of ingredients used traditionally in both carbon and iron gall inks (carbon based and tanning agents)." ${ }^{m 1}$ Although it is certainly difficult to describe all the hues that characterize this class of inks, the aforementioned definitions are quite generic. At least two main subgroups should be distinguished: carbon ink combined with plant ink, and carbon ink mixed with iron gall ink. ${ }^{42}$ The former was known and used: for example, the

40 Monique Zerdoun Bat-Yehouda, Les encres noires au Moyen Âge (jusq'à 1600 ) (Paris: CNRS Éditions, 2003), p. 20.

41 Adam Gacek, Arabic Manuscripts. A Vademecum for Readers (Leiden: Brill 2009), p. 133.

42 Only Schopen mentioned this division; Schopen, Tinten und Tuschen (cit. note 2), p. 14. A third group might also be recognized, carbon ink with the addition of metallic salts, but since the colour is given only by the carbon component, we consider it to be a subgroup 
Jewish philosopher Maimonides (d. 1204 CE) described it as the preferred ink for the writing of phylacteries. ${ }^{43}$ The mixed inks, combining carbon and iron gall inks, were also very popular in the Arab world since they combined the intense black colour and stability of the carbon ink with the indelibility of ferrogallic inks.

At times, the recipes instruct the reader to mix a complete ink from one typology with additional ingredients from a different typology: for example, Persian ink (carbon-based) with tannins, thus obtaining a mixed carbon-plant ink. But more often a list of ingredients of different ink typologies would be given, resulting in a "natural born" mixed ink. Moreover, the proportions of the ingredients could vary greatly, resulting in inks with very different behaviours and characteristics. In general, the authors of the treatises and the compilers do not give them a specific name but call them hibr (iron gall inks) or midād (carbon inks) depending on how close their characteristics are to the first or the second category. The same is true for the chapter in which they are included. The only exception is al-Marrākuš̄i, who grouped the mixed inks of both subgroups in a chapter dedicated to simple liquid midād and midād murakkab (composite ink).

The first attestations of recipes for mixed carbon-plant ink date from between the late 9 th century and the early 1oth century, since both ar-Rāzi and ibn Muqla ${ }^{44}$ described this typology in their treatises. This typology is not very representative, its formulas being only six per cent of the total, but parallels can be found with the Jewish tradition, especially with the so-called Maimonides' ink, which is a variant of the one described by ibn Muqla. ${ }^{45}$ The mixed carbon-iron gall inks represent 14 per cent of the formulas collected. The majority of the recipes can be found in al-Marrākušĩ and are ascribed to

of the class of carbon inks. Recipes with such a description can be found in Greco-Roman antiquity (by Dioscorides, 1st c.) and Jewish tradition from the 2nd c.; Zerdoun, Les encres noires (cit. note 30), pp. 79-81 and 105-110. No such recipe has been found among the Arabic texts.

43 Zerdoun, Les encres noires (cit. note 30), pp. 111-116.

44 Dominique Sourdel, "Ibn Mukla," in: Encyclopaedia of Islam, New Edition (cit. note 3), vol. III pp. 886b-887a; translations of his recipe in Schopen, Tinten und Tuschen (cit. note 2), p. 130 and Ahmed Mousa, Zur Geschichte der Islamischen Buchmalerei in Aegypten, Būlāq Cairo: Government Press 1931, p. 27.

45 Zerdoun, Les encres noires (cit. note 30), p. 111. 
him or his contemporaries, probably evidence of the increasing popularity of this medium at that time. ${ }^{46}$

Together, they represent 20 per cent of the formulas but their use is rarely attested in manuscripts. ${ }^{47}$ The results obtained by analysing some of the reproduced recipes of mixed ink show that the protocol currently in use is seldom successful in identifying them.

In general, Near infrared reflectography (NIR) is a quick and perfect method for dealing with a pure class ink, since carbon, plant, and iron gall inks have very distinct optical properties. However, no unequivocal identification of mixed inks seems possible, since a high amount of carbon masks the presence of other components when illuminated with NIR light. ${ }^{48}$ Ultra-violet reflectography (UV) can offer complementary data thanks to the tannins' property of quenching fluorescence, which enhances the contrast between a fluorescing background and the text, but here, too, the presence of carbon on the surface of the ink will partially or even completely mask the result, depending on how damaged the ink is.

Raman spectroscopy presents the cleanest and the most straightforward method for identifying carbon and iron gall inks and is therefore well suited to documenting a mixture of both. Unfortunately, despite the recent development of portable Raman spectrometers, the analysis of black inks still often requires a bench instrument or the extraction of samples in addition to trained personnel. Moreover, the detection limits of the different components (iron gall inks and carbon) need to be further tested. Furthermore, Raman measurements of plant inks and of mixed carbon-plant inks yield no conclusive spectra of tannins with lasers in the visible wavelength range (vIs). The situation is somewhat better when the excitation wavelength is shifted to the

46 In the recipe for the hibr used by Haalid ibn Barmak (d. 165/782) al-Marrākušī mentions a variant introduced by the vizier Yahyā b. Hālid (d. 19o/8o6), who was said to add myrobalan and oil soot to his father's preparation. This, then, would be the first attestation of such a mixed ink, see Fani, Le arti del libro (cit. note 2), pp. 100-101. The author of the Kitāb al-azhār, however, is cautious with the attribution and, in fact, he reported the news as something that "was told in Baghdad in the year $649 \mathrm{H} / 1251 \mathrm{CE}$," hinting that he had no written or more reliable source to confirm the rumours and perhaps that an authority was needed to empower and justify the use of the new style of ink.

47 For a summary of the results achieved and the techniques used, see: Claudia Colini, Oliver Hahn, Olivier Bonnerot, Simon Steger, Zina Cohen, Tea Ghigo, Thomas Christiansen, Marina Bicchieri, Paola Biocca, Myriam Krutzsch, Ira Rabin, "The Quest for the Mixed Inks," Manuscript cultures, 2018, 11:43-50.

48 Ralf Mrusek, Robert Fuchs, Doris Oltrogge, "Spektrale Fenster zur Vergangenheit. Ein neues Reflektographieverfahren zur Untersuchung von Buchmalerei und historischem Schriftgut," Naturwissenschaften, 1995, 82:68-79, p. 72. 
NIR region, but even in this case strong fluorescence of organic molecules considerably disturbs the spectrum. Surface-Enhanced-Raman-Spectroscopy (SERS) may overcome this difficulty; indeed, it has already been applied successfully to the analysis of modern paints and dyes. ${ }^{49}$ This is, however, a micro-invasive technique that, depending on the selected substrate, requires sampling. Attempts have been made, for cultural heritage purposes, to reduce the sample amount to a minimum and to optimize it. However, an optimized substrate and procedure for SERS on tannins and mixed inks must still be defined. ${ }^{50}$ Similar problems concern the application of Infra-Red Spectroscopy (FTIR) for the detection of tannins. The use of methods such as Laser Ablation for micro-sampling, however, could encourage the application of FTIR Spectroscopy in transmission. The accuracy of the results obtained using Mass Spectroscopy (MS), in particular Atmospheric Solids Analysis Probe Mass Spectoscopy (ASAP-MS), suggests that it could be an even more promising technique, but it still requires micro-sampling. ${ }^{51}$ The samples made with the aforementioned recipes are currently been used to test these methods.

\section{$8 \quad$ Conclusions}

The sentence "I tried it and it is really good," in all its declinations, can be found at the beginning or end of many recipes. This could easily be a topos of this technical literature and does not necessarily mean that the formulation was tested; ${ }^{52}$ it is only meant to give prestige and authority to the recipe. But we know that a few authors and compilers, such as al-Marrākušī, enacted the recipes or evaluated their feasibility by analogy. ${ }^{53}$ These elements, in addition to the easily observable fluidity of the tradition, suggest a "hands on" approach to the transmission of such texts, where practical experimentation was, if not common, at least considered an important and validating element. It is apparent both when the writer was copying a treatise from a specific Vorlage (case

49 Federica Pozzi, Marco Leona "Surface-enhancement Raman Spectroscopy in Art and Archaeology," Journal of Raman Spectroscopy, 2016, 47:67-77.

$5^{\circ} \quad$ Colini et al., The quest (cit. note 47), p. 49.

$5^{1}$ Tea Ghigo, Ira Rabin, Paola Buzi, "Black Egyptian inks in Late Antiquity: new insights on their manufacture and use", Archaeological and Anthropological Sciences 2020, 12:70 (1-10), pp. 5 and 11-12.

$5^{2}$ For example, no information is given regarding the ineffectiveness of recipes, although some of the formulations, when tested, did not give the expected results.

53 Al-Marrākušì uses this word to explain the process of testing a recipe on the basis of similar recipes that proved successful. 
study II), or when he was in the process of importing recipes from a treatise to form a new one (case studies III and $\mathrm{v}$ ).

Nowadays, the replication of ink recipes may fulfil several functions.

It proves helpful for finding mistakes and problematic points in the text of the recipes, such as erroneous corrections of terms or missing information (case study I-II), but also for understanding the order and organization, or lack thereof, of the treatise (case study III). It can also clarify the meaning of terms and expressions (case studies III and IV) and, in a broader view, it helps in assessing the real technical expertise of the writers, or at least the effort and attention that they put into writing their texts (case studies II, III, IV and v). Through the replication it is possible to prepare samples that, once analysed, can support the observations made on manuscripts by comparing their analytical results (case study v). Furthermore, the effectiveness of the current analytical protocols and equipment can be evaluated on the basis of which ingredients and ink typologies can be identified through their application (case study VI).

The case studies show the key role of the replication of recipes for both the Humanities and the Natural Sciences. The interdisciplinarity required to effectively carry out and comprehend the procedures clearly highlights the need of increasing the cooperation between scholars of different academic branches. 